\title{
Enhancement of Ethanol Production from Napiergrass (Pennisetum purpureum Schumach) by a Low-Moisture Anhydrous Ammonia Pretreatment
}

\author{
Masahide Yasuda $^{1 *}$, Keisuke Takeo ${ }^{1}$, Hayato Nagai ${ }^{1}$, Takuya Uto ${ }^{1}$, Toshifumi Yui ${ }^{1}$, \\ Tomoko Matsumoto ${ }^{2}$, Yasuyuki Ishii ${ }^{3}$, Kazuyoshi Ohta ${ }^{4}$ \\ ${ }^{1}$ Department of Applied Chemistry, Faculty of Engineering, \\ University of Miyazaki, Miyazaki, Japan \\ ${ }^{2}$ Center for Collaborative Research and Community Cooperation, \\ University of Miyazaki, Miyazaki, Japan \\ ${ }^{3}$ Department of Animal and Grassland Sciences, Faculty of Agriculture, \\ University of Miyazaki, Miyazaki, Japan \\ ${ }^{4}$ Department of Biochemistry and Applied Biosciences, Faculty of Agriculture, \\ University of Miyazaki, Miyazaki, Japan \\ Email: *yasuda@cc.miyazaki-u.ac.jp
}

Received July 18, 2013; revised August 18, 2013; accepted August 25, 2013

Copyright (C) 2013 Masahide Yasuda et al. This is an open access article distributed under the Creative Commons Attribution License, which permits unrestricted use, distribution, and reproduction in any medium, provided the original work is properly cited.

\begin{abstract}
Napiegrass (Pennisetum purpureum Schumach) was treated with a low-moisture anhydrous ammonia (LMAA) pretreatment by adding an equal weight of water and keeping it under atmospheric ammonia gas at room temperature for four weeks. After the removal of ammonia and washing with water, a simultaneous saccharification and fermentation (SSF) was conducted for the LMAA-pretreated napiergrass $(1.33 \mathrm{~g})$ in a buffer solution $(8 \mathrm{~mL})$ using a mixture of a cellulase $(80 \mathrm{mg})$ and a xylanase $(53 \mathrm{mg})$ as well as the cell suspension $(0.16 \mathrm{~mL})$ of Saccharomyces cerevisiae. Ethanol and xylose resulted in $91.2 \%$ and $62.9 \%$ yields, respectively. The SSF process was scaled up using LMAA-pretreated napiergrass $(100.0 \mathrm{~g})$ to give ethanol $(77.2 \%)$ and xylose $(52.8 \%)$. After the removal of ethanol, the pentose fermentation of the SSF solution $(40 \mathrm{~mL})$, which contained $1.00 \mathrm{~g}$ of xylose, using cell suspension of Escherichia coli KO11 (70 mL) gave $86.3 \%$ yield of ethanol. Total ethanol yield reached $68.9 \%$ based on xylan $(21.4 \mathrm{wt} \%)$ and glucan (39.7 $\mathrm{wt} \%$ ) of the LMAA-pretreated napiergrass.
\end{abstract}

Keywords: LMAA; SSF; Cellulase; Xylanase; Saccharomyces cerevisiae; Escherichia coli KO11

\section{Introduction}

Biomass has gained much attention as a new sustainable energy source alternative to petroleum-based fuels [1]. The second-generation bioethanol from lignocellulosic materials became a promising approach since the lingocelluloses are not directly in competition with food sources. However, a variety of pretreatment methods to remove the lignin components and/or to promote an enzymatic digestibility of the cellulosic components have been required for efficient bio-ethanol production from lignocellulose [2].

It has been known that cellulose chains are incorporated into a number of distinct crystal phases each dif-

"Corresponding author. fering in chemical reactivity and material characteristics. The naturally occurring crystal phases, cellulose I [3] can be transformed into cellulose IIII by treating them with liquid ammonia [4] or various amines [5-9]. Therefore, the ammonia fiber explosion (AFEX) pretreatment was performed by heating the biomass with ammonia gas at $90^{\circ} \mathrm{C}$ under 21 atm [10,11]. This was interpreted as an increase in the cellulose IIII phase which has a high reactivity toward enzymatic degradation [12]. Also, soaking in aqueous ammonia (SAA) at $40^{\circ} \mathrm{C}-80^{\circ} \mathrm{C}$ in a room atmosphere was used as the pretreatment of lignocellulose $[13,14]$. Recently, Kim et al. [15] developed a pretreatment using gaseous ammonia, low-moisture anhydrous ammonia (LMAA) pretreatment, where the lingocellulose was kept in a flask filled with ammonia gas at $80^{\circ} \mathrm{C}$ for $84 \mathrm{~h}$. 
We were interested in ethanol production from herbaceous lignocellulosic napiergrass (Pennisetum purpureum Schumach) because of its low lignin content and high harvest amount per year and per area [16,17]. Ethanol was produced from non-pretreated napiergrass through simultaneous saccharification and fermentation (SSF) as well as pentose fermentation (PF) with recombinant Escherichia coli KO11 [18]. However, the total ethanol yield was still low (44.2\%). Moreover, usual alkali-pretreatment did not operate effectively to enhance the ethanol yield [19]. Therefore, we applied a LMAA pretreatment to enhance the ethanol yield from napiergrass.

\section{Materials and Methods}

\subsection{LMAA Pretreatment}

The LMAA pretreatment was performed by modifying the Kim method [15]. Water (100 g) was added dropwise to the dry powdered napiergrass $(100 \mathrm{~g}$, volume $320 \mathrm{~mL})$ in the flask $(1 \mathrm{~L})$. The resulting moist powdered napiergrass in the flask was evacuated with a pump under 20 $\mathrm{mm} \mathrm{Hg}$ and then gaseous ammonia was introduced into the flask. This operation was performed three times until the atmosphere inside the flask was entirely replaced with ammonia. The amount of ammonia presented in the flask was $1.1 \mathrm{~g}$. The moist powdered napiergrass was kept under ammonia gas atmosphere at room temperature for four weeks. After the treatment, the ammonia was removed with an evaporator. The treated napiergrass was washed with water $(2 \mathrm{~L})$ three times to separate the brownish aqueous solution of the lignin. The treated napiergrass was dried at $60^{\circ} \mathrm{C}$ to weigh out the precise amount of napiergrass in the following biological treatment.

\subsection{Chemical Components of Napiergrass}

The powdered napiergrass $(30 \mathrm{~g})$ was treated with a $1 \%$ aqueous solution of $\mathrm{NaOH}(400 \mathrm{~mL})$ at $95^{\circ} \mathrm{C}$ for $1 \mathrm{~h}$. The holocellulose was isolated as a pale yellow precipitate from the treated mixture by centrifugation and filtration. The supernatant solution was neutralized to $\mathrm{pH} 5.0$ by a dilute $\mathrm{HCl}$ solution. The resulting dark brown precipitate identified as lignin was collected by centrifugation at $10,000 \mathrm{rpm}$ for $10 \mathrm{~min}$. Sugars in holocellolose were determined according to the methods published by the National Renewable Energy Laboratory (NREL) [20] as follows. Sulfuric acid $(72 \mathrm{wt} \%, 3.0 \mathrm{~mL})$ was added slowly to holocellulose (300 mg) and kept at $30^{\circ} \mathrm{C}$ for $1 \mathrm{~h}$. The resulting solution was diluted by water $(84 \mathrm{~mL})$ until the concentration of sulfuric acid was $4 \mathrm{wt} \%$. Acid hydrolysis was performed by autoclaving at $121^{\circ} \mathrm{C}$ for $1 \mathrm{~h}$ in an autoclave. After the neutralization by $\mathrm{CaCO}_{3}$, the solution was subjected to the centrifugation to give the supernatant solution (ca. $87 \mathrm{~mL}$ ), which was concentrated to $30 \mathrm{~mL}$ by evaporation. The solution was analyzed by HPLC. The peaks of glucose and xylose ap- peared whereas the peaks of galactose and arabinose were very weak because of their low contents. The amounts of glucan and xylan were determined from the amounts of glucose and xylose determined by HPLC. It was confirmed that the sum amounts of glucan and xylan were equaled to the amounts of hollocellolose. The ash component in lignocellulose was obtained by the burning of the lignocellulose $(2.0 \mathrm{~g})$ in an electric furnace (KBF784N1, Koyo, Nara, Japan) for $2 \mathrm{~h}$ at $850^{\circ} \mathrm{C}$. Thus, the chemical components of napiergrass were determined, as shown in Table 1.

\subsection{Hydrolytic Enzyme}

A cellulase from Acremonium cellulolyticus (Acremozyme KM, Kyowa Kasei, Osaka, Japan) was selected by comparing its activity with other cellulases such as Meycellase (Meiji Seika), a cellulase from Trichoderma viride (Wako Chemicals, Osaka, Japan) and a cellulase from Aspergillus niger (Fluka Japan, Tokyo) [18,21]. The cellulase activity of Acremozyme was determined to be 1320 units/mg by the method of breaking down filter paper [18]. A xylanases from Trichoderma longibrachiatum (reesei) (Sumizyme X, Shin Nihon Chemicals, Anjyo, Japan, $5000 \mathrm{u} / \mathrm{g}$ ) was selected from commercially available hemicellulase.

\subsection{Preparation of the Inoculum Culture of Saccharomyces cerevisiae and Escherichia coli KO11}

Saccharomyces cerevisiae NBRC 2044 was grown at $30^{\circ} \mathrm{C}$ for $24 \mathrm{~h}$ in a basal medium (initial $\mathrm{pH} 5.5$ ) consisting of glucose $(20.0 \mathrm{~g} / \mathrm{L})$, polypeptone $(1.0 \mathrm{~g} / \mathrm{L})$, yeast extract $(1.0 \mathrm{~g} / \mathrm{L}), \mathrm{KH}_{2} \mathrm{PO}_{4}(1.0 \mathrm{~g} / \mathrm{L})$, and $\mathrm{MgSO}_{4}(3.0$ $\mathrm{g} / \mathrm{L})$. After incubating for $24 \mathrm{~h}$, the cell suspension of $S$. cerevisiae whose grown culture of $S$. cerevisiae showed a cell density of $7.7 \times 10^{7}$ cells $/ \mathrm{mL}$, was obtained [18]. E. coli KO11 was grown in the LB medium $(200 \mathrm{~mL})$ consisting of tryptone $(2.0 \mathrm{~g} / \mathrm{L}$, Difco), yeast extract $(1.0$ $\mathrm{g} / \mathrm{L})$, and $\mathrm{NaCl}(2.0 \mathrm{~g} / \mathrm{L})$ under shaking at $150 \mathrm{rpm}$ at $37^{\circ} \mathrm{C}$ for $24 \mathrm{~h}$. The $\mathrm{KO} 11$ cell suspension contained a dry weight of $0.52 \mathrm{mg} / \mathrm{mL}$ of E. coli $\mathrm{KO} 11$.

Table 1. Components of the NO- and LMAA-pretreated napiergrass.

\begin{tabular}{ccccc}
\hline \multirow{2}{*}{$\mathrm{PT}^{\text {a) }}$} & \multicolumn{4}{c}{ Components/wt $\%$} \\
\cline { 2 - 5 } & $\begin{array}{c}\text { Holocellulose } \\
\text { (glucan : xylan) }\end{array}$ & Lignin & Ash & Others \\
\hline NO $^{\text {b) }}$ & $48.2(31.3: 16.9)$ & 12.6 & 13.9 & 25.3 \\
LMAA & $61.1(39.7: 21.4)$ & 7.1 & 7.1 & 24.7 \\
\hline
\end{tabular}

a) Pretreatment (PT): NO: non-treatment. LMAA: low-moisture anhydrous ammonia pretreatment at room temperature for four weeks. ${ }^{\text {b) }}$ The components of the LMAA-pretreatment napiergrass without washing with water was considered to be same as those of non-treated napiergrass. 


\subsection{Simultaneous Saccharification and Fermentation (SSF)}

The LMAA-pretreated napiergrass (1.33 g) was suspended in the acetate buffer $(5 \mathrm{~mL}, \mathrm{pH} 5.0)$ and then autoclaved at $121^{\circ} \mathrm{C}$ for $20 \mathrm{~min}$. After cooling to room temperature under UV-irradiation, the cell suspension $(0.16 \mathrm{~mL})$ of $S$. cerevisiae and the hydrolytic enzyme $(133 \mathrm{mg})$ in an acetate buffer solution $(3.0 \mathrm{~mL}, \mathrm{pH} 5.0)$ were added to the suspension of the LMAA-treated napiergrass [18]. After air was purged with $\mathrm{N}_{2}$, the SSF was initiated by stirring the solution vigorously with a magnetic stirrer at an optimal temperature of $34^{\circ} \mathrm{C}$. The evolved $\mathrm{CO}_{2}$ was collected over water by a messcylinder, and the reaction was monitored by the volume of $\mathrm{CO}_{2}$. The SSF reaction was continued for $48 \mathrm{~h}$ until $\mathrm{CO}_{2}$ evolution was ceased. Table 2 lists the data expressed as averages of the experiments in three times.

\subsection{Analysis}

Saccharides were analyzed on a high-performance liquid chromatography system (LC-20AD, Shimadzu, Kyoto, Japan) equipped with RI detector (RID-10A) using an anion exchange column (NH2P-50 4E; Shodex Asahipak, $250 \mathrm{~mm}$ in length and $4.6 \mathrm{~mm}$ in ID, Yokohama, Japan). Acetonitrile-water $(8: 2 \mathrm{v} / \mathrm{v})$ was flowed at $1.0 \mathrm{~mL} / \mathrm{min}$ as mobile phase. Ethanol was analyzed by gas-liquid chromatography using 2-propanol as an internal standard on a Shimadzu gas chromatograph (model GC-2014) equipped with a glass column of 5\% Thermon 1000 on Sunpak-A (Shimadzu).

\section{Results}

\subsection{Napiergrass as Lignocellulosic Materials}

For the herbaceous lignocellulose, we selected a dwarf type of napiergrass (Pennisetum purpureum Schumach), which is a digestible tropical grass [16,17]. Napiergrass was cultivated in the Kibana Agricultural Science Station, at the University of Miyazaki. Leaf blades of the napiergrass were separated from the stem and then cut by a cutter and dried at $70^{\circ} \mathrm{C}$ for $72 \mathrm{~h}$. The dried matter was ground until the $70 \%$ of the particles were in a range of $32-150 \mu \mathrm{m}$ in length.

\subsection{Strategy for Ethanol Production from Napiergrass}

In the case of lignocelluloses with high xylan contents, $\mathrm{PF}$ is an unavoidable process. In many cases, the PF using recombinant $E$. coli [22-24] or recombinant $S$. cerevisiae [25] has been incorporated with the process as cofermentation with hexose fermentation $[15,26]$. However, we performed the PF step separately, since HF using S. cerevisiae was well-established technique. Our process outline proceeded through SSF using a hydrolytic enzyme and S. cerevisiae followed by PF using $E$. coli KO11.

\subsection{SSF of the LMAA-Pretreated Napiergrass}

The results of the SSF process were summarized in Table 2. Without the pretreatment, the SSF using cellulase (Acremozyme KM) produced ethanol and xylose in

Table 2. The product yields in the SSF of napiergrass ${ }^{\text {a) }}$.

\begin{tabular}{|c|c|c|c|c|c|c|}
\hline \multirow{2}{*}{ Run } & \multirow{2}{*}{$\mathrm{PT}^{\mathrm{c})}$} & \multirow{2}{*}{$F_{\mathrm{X}}{ }^{\mathrm{d})}$} & \multicolumn{3}{|c|}{ Product/mg (Yield/\%) ${ }^{\text {b) }}$} & \multirow{2}{*}{ Ethanol/g L ${ }^{-1 e)}$} \\
\hline & & & Glucose & Xylose & Ethanol & \\
\hline $1^{\mathrm{f})}$ & NO & 0.0 & $13 \pm 2(2.8)$ & $77 \pm 29(30.8)$ & $122 \pm 15(51.6)$ & 15.3 \\
\hline 2 & LMAA & 0.0 & $32 \pm 4(5.5)$ & $150 \pm 14(47.6)$ & $179 \pm 3(59.7)$ & 22.4 \\
\hline 3 & LMAA & 0.1 & $25 \pm 4(4.2)$ & $172 \pm 5(53.5)$ & $182 \pm 4(60.5)$ & 22.8 \\
\hline 4 & LMAA & 0.2 & $20 \pm 2(3.5)$ & $155 \pm 14(48.9)$ & $197 \pm 1(65.7)$ & 24.6 \\
\hline 5 & LMAA & 0.3 & $22 \pm 2(3.7)$ & $160 \pm 3(50.5)$ & $219 \pm 22(72.9)$ & 27.3 \\
\hline 6 & LMAA & 0.4 & $18 \pm 10(3.1)$ & $199 \pm 18(62.9)$ & $273 \pm 7$ (91.2) & 34.2 \\
\hline 7 & LMAA & 0.5 & $14 \pm 1(2.3)$ & $173 \pm 2(54.8)$ & $260 \pm 10(86.5)$ & 32.4 \\
\hline 8 & LMAA & 0.6 & $23 \pm 22(4.0)$ & $146 \pm 5(46.3)$ & $197 \pm 8(65.5)$ & 24.0 \\
\hline 9 & LMAA & 0.7 & $26 \pm 10(4.4)$ & $150 \pm 9(47.6)$ & $198 \pm 12(66.0)$ & 24.7 \\
\hline $10^{\mathrm{f})}$ & NO & 0.4 & $142 \pm 35(30.7)$ & $120 \pm 23(48.3)$ & $98 \pm 1(41.3)$ & 12.2 \\
\hline $11^{\mathrm{f}}$ & LMAA $^{\mathrm{g})}$ & 0.4 & $34 \pm 16(7.4)$ & $133 \pm 6(45.2)$ & $178 \pm 4(75.1)$ & 22.3 \\
\hline
\end{tabular}

a) The SSF was performed for the pretreated napiergrass $(1.33 \mathrm{~g})$ in buffer solution $(8 \mathrm{~mL})$ containing hydrolytic enzyme (133 $\mathrm{mg})$ and the cell suspension of $S$. cerevisiae $(0.16 \mathrm{~mL})$ at $34^{\circ} \mathrm{C}$ for $48 \mathrm{~h}$. The data were expressed as averages of three experiments. ${ }^{b}$ In the case of LMAA, the yields of glucose, xylose, and ethanol were calculated based on the theoretical amounts, $587 \mathrm{mg}, 316 \mathrm{mg}$, and $300 \mathrm{mg}$, respectively; ${ }^{\text {c) }}$ Pretreatment (PT). NO: non-treatment. LMAA: low-moisture anhydrous ammonia pretreatment at room temperature for four weeks. ${ }^{\mathrm{d})}$ The $F_{\mathrm{X}}$ was the fraction of xylanase in the mixture (133 mg) of cellulase and xylanase. ${ }^{\text {e) }}$ Concentration of ethanol in $\mathrm{g} \mathrm{L}^{-1}$. f) The yields of glucose, xylose, and ethanol were calculated based on the theoretical amounts, 463 mg, 249 $\mathrm{mg}$, and $237 \mathrm{mg}$, respectively. ${ }^{\mathrm{g}}$ In the case of the LMAA-pretreatment without washing with water. 
$51.6 \%$ and $30.8 \%$ yields, respectively (run 1). In the LMAA-pretreated napiergrass case, the yields of ethanol and xylose increased to $59.7 \%$ and $47.6 \%$ yields, respectively (run 2). However, the yields were still low. Therefore, we used a xylanase (Sumizyme $\mathrm{X}$ ) in addition to the cellulase. The fraction of xylanase $\left(F_{X}\right)$ in the mixture (133 mg) of cellulase and xylanase was defined. The maximum yields were observed at 0.4 of $F_{X}$ among 0.1 0.7 of $F_{X}$ (runs 3-9). The yields of ethanol and xylose reached $91.2 \%$ and $62.9 \%$, respectively under the optimal condition of the SSF where the LMAA-pretreated napiergrass $(1.33 \mathrm{~g})$ was treated in a buffer solution (8 $\mathrm{mL})$ using cellulase $(80 \mathrm{mg})$, xylanase $(53 \mathrm{mg})$, and the cell suspension $(0.16 \mathrm{~mL})$ of $S$. cerevisiae (run 6). On the other hand, in the non-treated napiergrass case, the ethanol yield was still low even at 0.4 of $F_{X}$ (run 10 ). In the case of LMAA-pretreatment that was not washed with water (run 11), the ethanol yield was 75.1\%. This showed that washing with water was needed to enhance the ethanol yield.

\subsection{Pentose Fermentation with $E$. coli KO11}

The SSF process was scaled up under optimized conditions of an acetate buffer $(600 \mathrm{~mL})$ containing cellulase $(6.0 \mathrm{~g})$, xylanase $(4.0 \mathrm{~g})$, the suspension of $S$. cerevisiae $(12.0 \mathrm{~mL})$, and the LMAA-pretreated napiergrass $(100 \mathrm{~g})$ was stirred at $34^{\circ} \mathrm{C}$. After the SSF for $18 \mathrm{~h}, 17.4 \mathrm{~g}$ $(77.2 \%)$ of ethanol and $12.6 \mathrm{~g}(52.8 \%)$ of xylose were formed whereas $2.2 \mathrm{~g}(5.0 \%)$ of glucose remained unchanged. Ethanol was removed from the SSF-treated solution $(600 \mathrm{~mL})$ by distillation under a reduced pressure until the volume of the residual solution reached 500 $\mathrm{mL}$. The condensed SSF solution contained $25.2 \mathrm{~g} / \mathrm{L}$ of xylose and $4.4 \mathrm{~g} / \mathrm{L}$ of glucose.

A portion $(50-80 \mathrm{~mL})$ of the inoculum culture $E$. coli KO11 was poured into the condensed SSF solution (40 $50 \mathrm{~mL}$ ). After $\mathrm{pH}$ was adjusted to 6.6 , the $\mathrm{PF}$ was performed by shaking the solution at $150 \mathrm{rpm}$ at $37^{\circ} \mathrm{C}$ for 96 h. The yields of ethanol are summarized in Table 3 . Ethanol (531 mg) was obtained under optimal conditions where the cell suspension of E. coli KO11 (70 mL) and SSF solution $(40 \mathrm{~mL})$ were used (run 4). Since the glucose disappeared after being fermented by E. coli KO11, it was assumed that the glucose was entirely turned to ethanol. Therefore, the ethanol amount produced from xylose was calculated to be $441 \mathrm{mg}$ by subtracting $90 \mathrm{mg}$ from $531 \mathrm{mg}$. Thus, the ethanol yield from xylose was determined to be $86.3 \%$.

\section{Discussion}

Usual pretreatment of lignocelluloses has been performed by the removal of the lignin-component using an alkali-pretreatment. However, it was found that the al- kali-pretreatment was not a useful method for the biological process of napiergrass with its low lignin-content, because of the retardation of the fermentation rate by the inhibitory materials derived from the alkali-pretreatment and the loss of nutrients for the fermentation [19]. The LMAA-pretreatment did not take place in the retardation of fermentation, as shown in Figure 1 where the time profile of $\mathrm{CO}_{2}$ evolution per $1 \mathrm{~g}$ of hollocellulose were compared among LMAA-pretreated, non-treated, and alkali-pretreated napiergrass. Moreover, it is possible to easily recycle gaseous ammonia with low energy in LMAA-pretreatment compared with the AFEX and SAA pretreatments which demanded energy to strip and recover ammonia from aqueous ammonia. Thus, the LMAA-pretreatment will be one of the useful pretreatment method that can be achieved with low energy to enhance the SSF processes of lignocelluloses.

\section{Conclusion}

A successfully efficient bio-ethanol production from napiergrass was achieved by the combination of the LMAA-pretreatment, the SSF used a mixture of cellulase and xylanase, and the pentose was fermented by $E$. coli KO11. The total mass balance was constructed in Figure 2. With $100 \mathrm{~g}$ of the LMAA-pretreated napiergrass, $24.1 \mathrm{~g}$ of ethanol can be totally produced through SSF and PF. The total ethanol yield reached $68.9 \%$ based on the amounts of xylan (21.4 g) and glucan (39.7 g) in

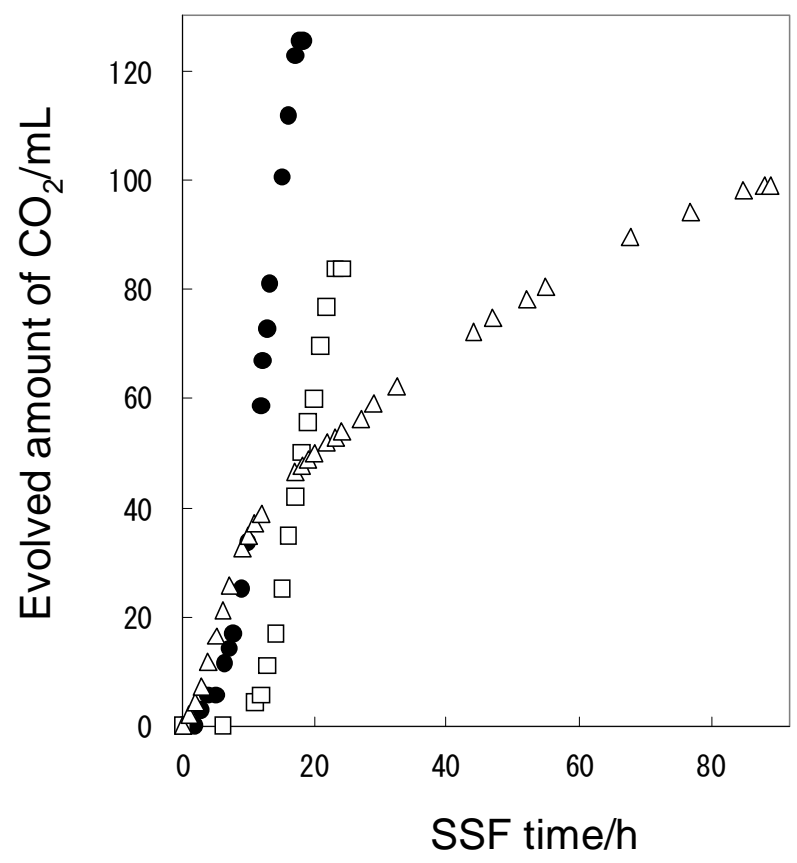

Figure 1. The time-conversion of $\mathrm{CO}_{2}$ evolved from the SSF reaction of LMAA-treated $(\odot)$, non-treated $(\square)$, and alkali-treated $(\triangle)$ napiergrass. The amounts of $\mathrm{CO}_{2}$ were presented as the evolved $\mathrm{CO}_{2}$ from $1.0 \mathrm{~g}$ of holocellolose. 
Table 3. Pentose fermentation with $E$. coli KO11.

\begin{tabular}{|c|c|c|c|c|c|}
\hline Run & $\mathrm{KO} 11 / \mathrm{mL}^{\mathrm{a})}$ & $\mathrm{SSF} / \mathrm{mL}^{\mathrm{b})}$ & Xylose $/ \mathrm{mg}(\text { Yield/\%) })^{\mathrm{c}}$ & Ethanol/mg (Yield/\%) $)^{\mathrm{d})}[\text { Yield/\% }]^{\mathrm{e})}$ & Ethanol $/ g \cdot L^{-1 f)}$ \\
\hline 1 & 50 & 50 & $807 \pm 9(64.0)$ & $352 \pm 28(46.5)[37.2]$ & 3.52 \\
\hline 2 & 60 & 50 & $457 \pm 122(36.3)$ & $440 \pm 75(58.1)[50.8]$ & 4.00 \\
\hline 3 & 70 & 30 & $0(0.0)$ & $309 \pm 3(72.0)[68.6]$ & 3.09 \\
\hline 4 & 70 & 40 & $0(0.0)$ & $531 \pm 4(88.4)[86.3]$ & 4.82 \\
\hline 5 & 70 & 50 & $60 \pm 10(4.7)$ & $594 \pm 77(77.5)[73.6]$ & 4.95 \\
\hline 6 & 80 & 50 & $86 \pm 38(6.7)$ & $540 \pm 59(70.4)[65.4]$ & 4.15 \\
\hline
\end{tabular}

a) The volume of the cell suspension of E. coli KO11 in $\mathrm{ml}^{\mathrm{b})}$ Pentose fermentation was performed for the SSF solution which contained $25.2 \mathrm{~g} \cdot \mathrm{L}^{-1}$ of $\mathrm{xylose}$ and $4.4 \mathrm{~g} \cdot \mathrm{L}^{-1}$ of glucose. ${ }^{\mathrm{c})}$ Recovered xylose. ${ }^{\mathrm{d})}$ The values in parenthesis are ethanol yields from both xylose and glucose. ${ }^{\mathrm{e})}$ The values in blanket are the ethanol yields from xylose. ${ }^{\mathrm{f})}$ Concentration of ethanol in $\mathrm{g} \cdot \mathrm{L}^{-1}$.

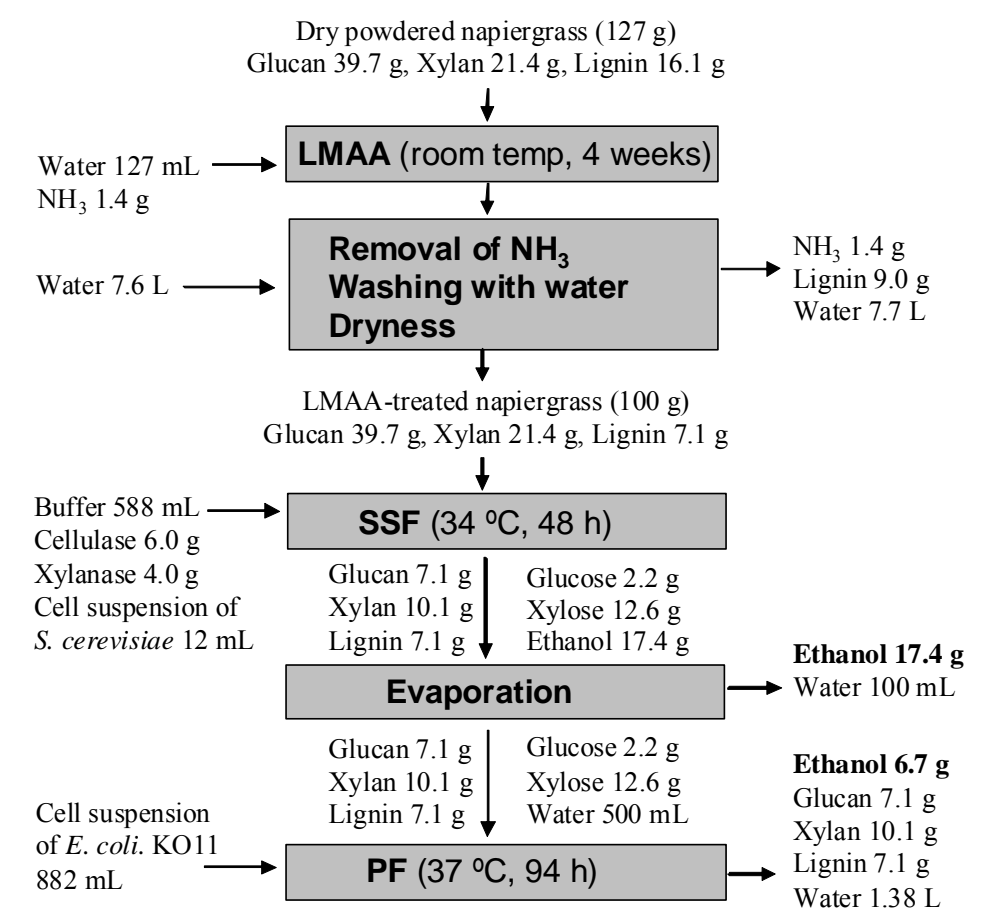

Figure 2. Process outline and total mass balance from LMAA-pretreated napiergrass (100 g).

$100 \mathrm{~g}$ of LMAA-pretreated napiergrass. If the PF process was combined with the SSF process run 6 of Table 2 which was run under optimal conditions of the small scale using $1.33 \mathrm{~g}$ of LMAA-pretreated napiergrass, the total yield will become $80.5 \%$.

\section{Acknowledgements}

We sincerely thank Lonnie O. Ingram from the University of Florida for providing the E. coli KO11 strain. This study was done as a part of the project entitled "Research and Development of Catalytic Process for Efficient Conversion of Cellulosic Biomass into Biofuels and Chemicals (2009-2013)" through Special Funds for Education and Research from the Ministry of Education, Culture, Sports, Science, and Technology of Japan.

\section{REFERENCES}

[1] M. Galbe and G. Zacchi, "Pretreatment of Lignocellulosic Materials for Efficient Bioethanol proDuction," Advances Biochemical Engineering/Biotechnology, Vol. 108, No. 3, 2007, pp. 41-65. doi:10.1007/10 $2007 \quad 070$

[2] P. Alvira, E. Tomás-Pejó, M. Ballesteros and M. J. Negro, "Pretreatment Technologies for an Efficient Bioethanol Production Process Based on Enzymatic Hydrolysis: A Review," Bioresource Technology, Vol. 101, No. 13, 2010, pp. 4851-4861. doi:10.1016/j.biortech.2009.11.093

[3] R. H. Attala and D. L. VanderHart, "Native Cellulose: A Composite of Two Distinct Crystalline Forms," Science, Vol. 223, No. 4633, 1984, pp. 283-285. doi:10.1126/science.223.4633.283

[4] M. A. Rousselle, M. L. Nelson, C. B. Hassenboehler Jr. and D. C. Legendre, "Liquid-Ammonia and Caustic Mer- 
cerization of Cotton Fibers: Changes in Fine Structure and Mechanical Propertied," Textile Research Journal, Vol. 46, No. 4, 1976, pp. 304-310.

[5] J. J. Creely and R. H. Wade, "Complexes of Diamines with Cellulose: Study of Symmetrical and Unsymmetrical Terminal Group Effects," Textile Research Journal. Vol. 45, No. 5, 1975, pp. 240-246. doi:10.1177/004051757504500309

[6] J. J. Creely and R. H. Wade, "Complexes of Cellulose with Cyclic Amines and Diamines," Journal of Polymer Science Part C Polymer Letters, Vol. 16, No. 6, 1978, pp. 291-295. doi:10.1002/pol.1978.130160608

[7] M. Wada, L. Heux, A. Isogai, Y. Nishiyama, H. Chanzy and J. Sugiyama, "Improved Structural Data of Cellulose IIII Prepared in Supercritical Ammonia," Journal of Macromolecules, Vol. 34, No. 5, 2001, pp. 1237-1243. doi:10.1021/ma001406z

[8] M. Wada, H. Chanzy, Y. Nishiyama and P. Langan, "Cellulose III I Crystal Structure and Hydrogen Bonding by Synchrotron X-Ray and Neutron Fiber Diffraction," Macromolecules, Vol. 37, No. 23, 2004, pp. 8548-8555. doi: $10.1021 / \mathrm{ma} 0485585$

[9] H. Chanzy, B. Henrissat, M.Vincendon, S. Tanner and P. S. Belton, "Solid-State 13C-N.M.R. and Electron Microscopy Study on the Reversible Cellulose I $\rightarrow$ Cellulose IIII Transformation in Valonia," Carbohydrate. Research, Vol. 160, 1987, pp. 1-11. doi:10.1016/0008-6215(87)80299-9

[10] F. Teymouri, L.Lauerano-Perez, H. Alizadeh and B. E. Dale, "Optimization of the Ammonia Fiber Explosion (AFEX) Treatment Parameters for Enzymatic Hydrolysis of Corn Stover," Bioresource Technology, Vol. 96, No. 18, 2005, pp. 2014-2018. doi:10.1016/j.biortech.2005.01.016

[11] M. W. Lau, B. E. Dale and V. Balan, "Ethanolic Fermentation of Hydrolysates from Ammonia Fiber Expansion (AFEX) Treated Corn Stover and Distillers Grain without Detoxification and External Nutrient Supplementation," Biotechnology and Bioengineering, Vol. 99, No. 3, 2008, pp. 529-539. doi:10.1002/bit.21609

[12] K. Igarashi, M. Wada and M. Samejima, "Activation of Crystalline Cellulose to Cellulose IIII Results in Efficient Hydrolysis by Cellobiohydrolase," FEBS Journal, Vol. 274, No. 7, 2007, pp. 1785-1792. doi:10.1111/j.1742-4658.2007.05727.x

[13] T.-H. Kim and Y. Y. Lee, "Pretreatment of Corn Stover by Soaking in Aqueous Ammonia," Applied Biochemistry and Biotechnology Part A Enzyme Engineering and Biotechnology, Vol. 124, No. 1-3, 2005, pp.1119-1132. doi:10.1385/ABAB:124:1-3:1119

[14] J.-K. Ko, J.-S. Bak, M.-W. Jung, H.-J. Lee, I.G. Choi and T.-H. Kim, "Ethanol Production from Rice Straw Suing Optimized Aqueous-Ammonia Soaking Pretreatment and Simultaneous Saccharification and Fermentation Processes," Bioresource Technology, Vol. 100, No. 19, 2009, pp. 4374-4380. doi:10.1016/j.biortech.2009.04.026

[15] C. G. Yoo, N. P. Nghiem, K. B. Hicks and T. H. Kim, "Pretreatment of Corn Stover by Low Moisture Anhydrous Ammonia (LMAA) Process," Bioresource Technology, Vol. 102, No. 21, 2011, pp. 10028-10034. doi:10.1016/j.biortech.2011.08.057

[16] Y. Ishii, N. Yamaguchi and S. Idota, "Dry Matter Production and in Vitro Dry Matter Digestibility of Tillers among Napiergrass (Pennisetum purpureum Schumach) Varieties," Grassland Science, Vol. 51, No. 2, 2005, pp. 153-163. doi:10.1111/j.1744-697X.2005.00021.X

[17] K. Rengsirikul, Y. Ishii, K. Kangvansaichol, P. Pripanapong, P. Sripichitt, V. Punsuvon, P. Vaithanomsat, G. Nakamanee and S. Tudsri, "Effects of Inter-Cutting Interval on Biomass Yield, Growth Components and Chemical Composition of Napiergrass (Pennisetum purpureum Schumach) Cultivars as Bioenergy Crops in Thailand," Grassland Science, Vol. 57, No. 2, 2011, pp. 135141. doi:10.1111/j.1744-697X.2011.00220.x

[18] M. Yasuda, A. Miura, T. Shiragami, J. Matsumoto, I. Kamei, Y. Ishii and K. Ohta, "Ethanol Production from Non-Pretreated Napiergrass through a Simultaneous Saccharification and Fermentation Process Followed by a Pentose Fermentation with Escherichia coli KO11," Journal of Bioscience and Bioengineering, Vol. 114, No. 2, 2012, pp. 188-192. doi:10.1016/j.jbiosc.2012.03.011

[19] M. Yasuda, K. Takeo, T. Matsumoto, T. Shiragami, Y. Matsushita, K. Sugamoto and Y. Ishii, "Effectiveness of Lignin-Removal in Simultaneous Saccharification and Fermentation of Napiergrass, Rice Straw, Silbergrass and Bamboo with Different Lignin-Contents," In: A. K. Chandel and S. Silverio da Silva, Eds., Sustainable Degradation of Lignocellulosic Biomass-Techniques, Applications and Commercialization, InTech, Croatia, Chapter 4, 2013, pp. 91-104.

[20] A. Sluiter, B. Hames, R. Ruiz, C. Scarlata, J. Sluiter, D. Templaton and D. Crocker, "Determination of Structural Carbohydrates and Lignin in Biomass," Technical Report NREL/TP-510-42618, National Renewable Energy Laboratory, Golden, 2010.

[21] M. Yasuda, A. Miura, R. Yuki, Y. Nakamura, T. Shiragami, Y. Ishii and $\mathrm{H}$. Yokoi, "The Effect of $\mathrm{TiO}_{2-}$ Photocatalytic Pretreatment on the Biological Production of Ethanol from Lignocelluloses," Journal of Photochemistry and Photobiology A: Chemistry, Vol. 220, No. 2-3, 2011, pp. 195-199. doi:10.1016/j.jphotochem.2011.04.019

[22] S. A. Underwood, M. L. Buszko, K. T. Shanmugam and L. O. Ingram, "Flux through Citrate Synthase Limits the Growth of Ethanologenic Escherichia coli KO11 during Xylose Fermentation," Applied and Environmental Microbiology, Vol. 68, No. 3, 2002, pp. 1071-1081. doi:10.1128/AEM.68.3.1071-1081.2002

[23] K. Ohta, F. Alterthum and L. O. Ingram, "Effects of Environmental Conditions on Xylose Fermentation by Recombinant Escherichia coli," Applied and Environmental Microbiology, Vol. 56, No. 2, 1990, pp. 463-465.

[24] K. Ohta, D. S. Beall, J. P. Mejia, K. T. Shanmugam and L. O. Ingram, "Genetic Improvement of Escherichia coli for Ethanol Production: Chromosomal Integration of Zymomonas mobilis Genes Encoding Pyruvate Decarboxylase and Alcohol Dehydrogenase II," Applied and Environmental Microbiology, Vol. 57, No. 4, 1991, pp. 893-900.

[25] A. Matsushika, H. Inoue, T. Kodaki and S. Sawayama, 
"Ethanol Production from Xylose in Engineered Saccharomyces cerevisiae Strains: Current State and Perspectives," Applied Microbiology and Biotechnology, Vol. 84, No. 1, 2009, pp. 37-53. doi:10.1007/s00253-009-2101-X

[26] S. K. Brandon, L. N. Sharma, G. M. Hawkins, W. F. An- derson, C. K. Chambliss and J. Doran-Peterson, "Ethanol and Co-Product Generation from Pressurized Batch Hot Water Pretreated T85 Bermudagrass and Merkeron Napiergrass using Recombinant Escherichia coli as Biocatalyst," Biomass Bioengineering, Vol. 35, No. 8, 2011, pp. 3667-3673. doi:10.1016/j.biombioe.2011.05.021 